\title{
The Quaternary Geological History of the Santa Catarina Southeastern Region (Brazil)
}

\author{
FRANCISCO CARUSO JR. ${ }^{1}$, KENITIRO SUGUIO ${ }^{2}$ and TOSHIO NAKAMURA ${ }^{3}$ \\ ${ }^{1}$ CTTMAR, Universidade do Vale do Itajaí, Cx. Postal 360 - 88301-970 Santa Catarina, Brazil \\ ${ }^{2}$ Instituto de Geociências, Universidade de São Paulo, Cx. Postal 11.348 - 05422-970 São Paulo, Brazil \\ ${ }^{3}$ Dating and Materials Research Center, Nagoya University, Japan
}

Manuscript received on May 10, 1999; accepted for publication on December 28, 1999;

contributed by KenITIRO SUGUIO*

\begin{abstract}
This paper supply subsidies for Quaternary geological reconstruction of the southeastern State of Santa Catarina coast in Brazil, being based on detailed geological mapping supported by a series of drilling data, which allowed to establish a stratigraphical hierarchy of the sedimentary deposits. Among the mapped geological units stand out the extensive Pleistocene shallow marine sandy sediments, which are commonly referred as a barrier island - lagoonal depositional system. A drilling campaign done in the domain permitted the sampling of material for ${ }^{14} \mathrm{C}$ datings, and the obtained data confirmed some previously assumed ages. The sequence of events, that originated the Holocene deposits, has been also reconstructed through drilling and ${ }^{14} \mathrm{C}$ dating of the collected peat and shell samples. Finally, the main characteristics of the most promising mineral prospect of the area, represented by voluminous calcareous shell deposits associated with Holocene sediments, are also presented.
\end{abstract}

Key words: quaternary geology, depositional system, calcareous shell deposits, Santa Catarina coastal area.

\section{STUDIED AREA}

The area is located in the northern half of the southern State of Santa Catarina (Brazil), between Paulo Lopes and Jaguaruna. Landward it is constituted by the "Escudo Catarinense" shield, and oceanward by the Florianópolis platform. This shield is composed by volcano-sedimentary rocks and granitoids of Archean to Proterozoic ages, being partially covered at the western portion by sedimentary and volcanic rocks of the Paraná intracratonic basin, whose ages are changeable from Silurian to Cretaceous. The Florianópolis platform, according to Gonçalves

Correspondence to: Francisco Caruso Jr.

* Member of the Academia Brasileira de Ciências

E-mail: carusojr@cttmar.univali.br et al. (1979), is situated between Santos and Pelotas sedimentary basins, at north and south, respectively.

\section{DEPOSITIONAL SYSTEMS OF THE COASTAL PLAIN}

There are two types of siliciclastic depositional systems: alluvial fan and barrier island/lagoonal systems, the first one dominated by continental processes, and the second one characterized by transitional and shallow marine environments (Villwock et al. 1986).

The so called Tubarão plain is an extensive lagoonal system, occupying an embayment in the "Escudo Catarinense" shield, and isolated from the open ocean by multiple sand barriers. They are attached to the Precambrian crystalline rock promontories, 
being formed as a consequence of important Quaternary sea-level changes.

The inner portion of this coastal plain is characterized by flat bottom valleys of the Araçatuba, D’Una, Aratingaúba, Capivari, Tubarão and Sangão rivers, filled by coarse fluvial sediments. They are intercalated and/or interlongued with coalescent alluvial fans or with lagoonal and shallow marine sediments, at their proximal or distal portions, respectively (Fig. 1).

The barrier island/lagoonal system is established on continental deposits after their partial reworking during the Quaternary sea-level changes. At least two times, the first one during the upper Pleistocene Sangamon and the second one during the Holocene high sea-level episodes, they exhibited three perfectly individualized subsystems: sand barrier, lagoon and inlet.

\section{THE PLEISTOCENE DEPOSITIONAL SYSTEM}

This unit can be correlated with barrier island/lagoonal system III of Villwock et al. (1986), to the Cananéia Formation of Suguio \& Petri (1973), or to the Penultimate Transgression deposits of Bittencourt et al. (1979). Genetically this depositional system can be correlated to the upper Pleistocene transgressive episode, whose culmination stage occurred about $120 \mathrm{ky} \mathrm{BP}$. Its sandy facies are assumed to be deposited in beach to shallow marine environments, with superficial eolian reworking. The beach deposits are dominantly quartzose, very fine to medium grained, yellowish to brownish colour sands, sometimes exhibiting trough cross-beddings and Callichirus burrows (Fig. 2). The eolian sands are also dominantly quartzose, fine to very fine grained, brownish to reddish yellow coloured, frequently presenting secondary clayish matrix and iron oxide cement.

Parallel horizontal and through cross-beddings frequently observed in the Pleistocene outcrops (Fig. 3) suggest that their deposition occurred in shallow marine environments. They are very often reworked at the surface, being overlain by massive eo- lian sands. Their outcrops suggest that the ancient sea-level was situated $8 \pm 2 \mathrm{~m}$ above the present one.

The establishment of an extensive coastal lagoon during the upper Pleistocene originated contemporaneous lagoonal terraces bordering the Mirim-Imuraí-Santo Antonio lagoonal system. Besides these morphological features, shallow drillings revealed the presence of clayey and peaty lagoonal deposits, underlying barrier island/lagoonal system III sandy deposits.

A drilling at north of Mirim Lagoon (28¹2’33”S/4043’05’'W), near Nova Brasília town, showed only fine to very fine yellowish sands, from the surface to the depth of $9.50 \mathrm{~m}$, being followed by $0.50 \mathrm{~m}$ thick peat, $0.60 \mathrm{~m}$ thick clay, and fine to medium grained yellowish sands (Fig. 4). The basal sand probably belongs to beach and eolian origin, which was followed by lagoonal paleoenvironment. The peat sample supplied age of $43 \mathrm{ky} \mathrm{BP}$ (NUTA-3311), according to the "Dating and Materials Research Center" of the Nagoya University (Japan). This ${ }^{14} \mathrm{C}$ age confirms the Pleistocene age of the peat, and this clayey-peaty sediments represent the 120 ky BP Sangamon transgression, which is superimposed by eolian sands.

Another drilling at Guaiúba Beach ( $28^{\circ} 17^{\prime} 10^{\prime \prime} \mathrm{S} / 48^{\circ} 42^{\prime} 07^{\prime \prime} \mathrm{W}$ ), at south of the Imbituba airport, was done at the foot of the eolian sands outcrop, constituted by eolian sands impregnated by organic matter, which has been considered as belonging to the Sangamon transgression by Bigarella \& Becker (1975), due to its minimum age of $35 \mathrm{ky}$ BP. This outcrop was integrated with the subsurface data which showed only eolian sands until a peat bed underlain by clayey deposit, and finally by a sand (Fig. 5). The peat sample dated at the above mentioned laboratory indicated a minimum age of $41 \mathrm{ky}$ BP. Assuming that this peat is representing a swampy environment following a coastal lagoonal episode related to the Sangamon transgression, the organic matter rich eolian sands, dated by Bigarella $\&$ Becker (1975), could be more recent than supposed by these authors. 


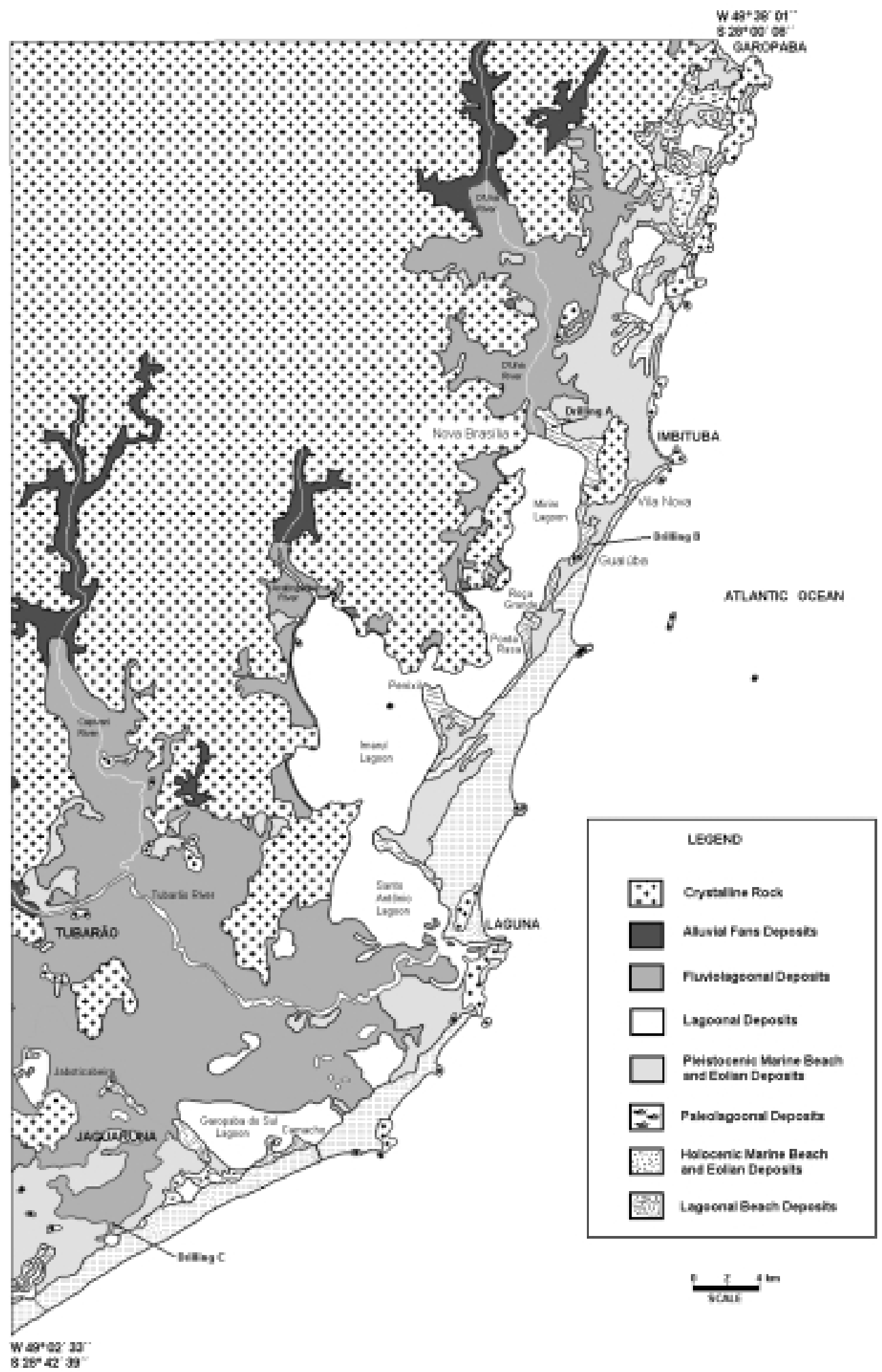

Fig. 1 - Geological map (simplified) of the studied area. 


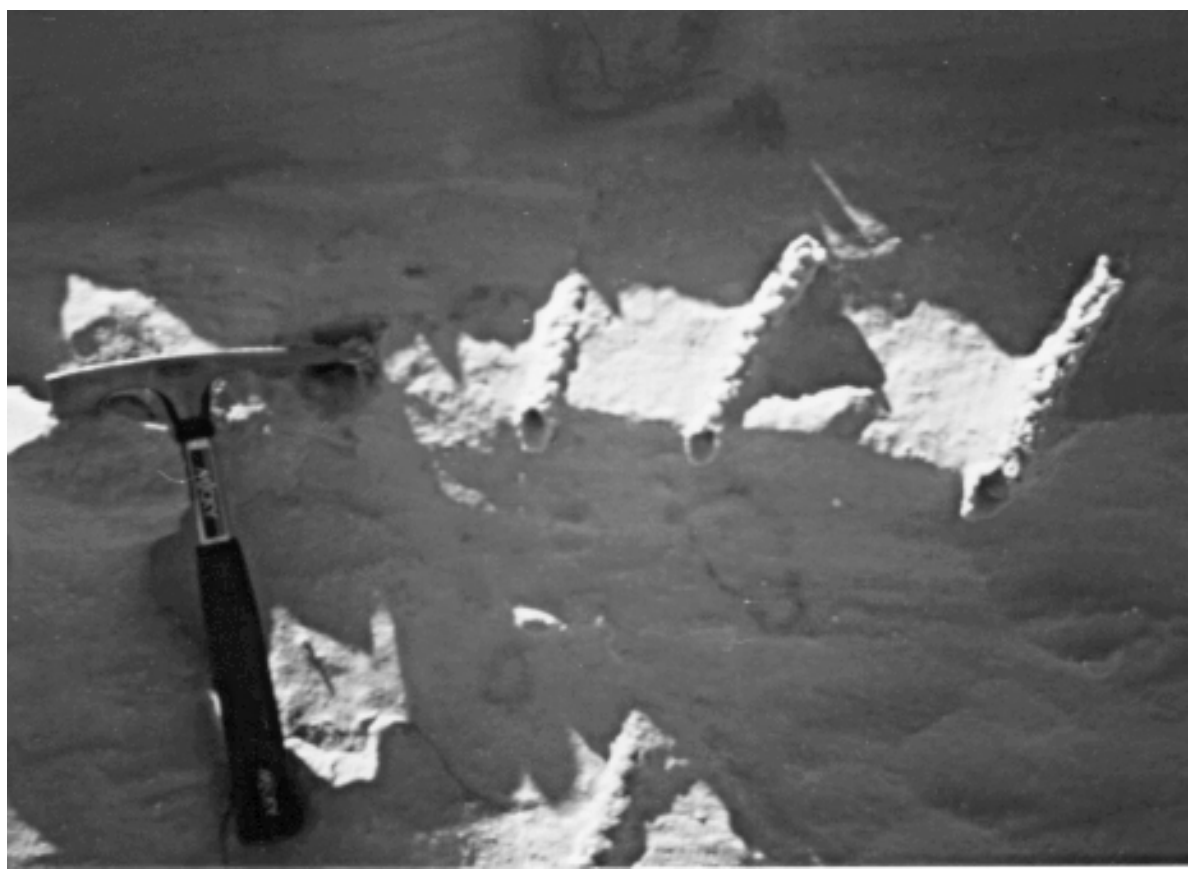

Fig. 2 - Biogenic burrows observed is a shallow marine sand of Pleistocene age, probably due to Callichirus, near Paulo Lopes.

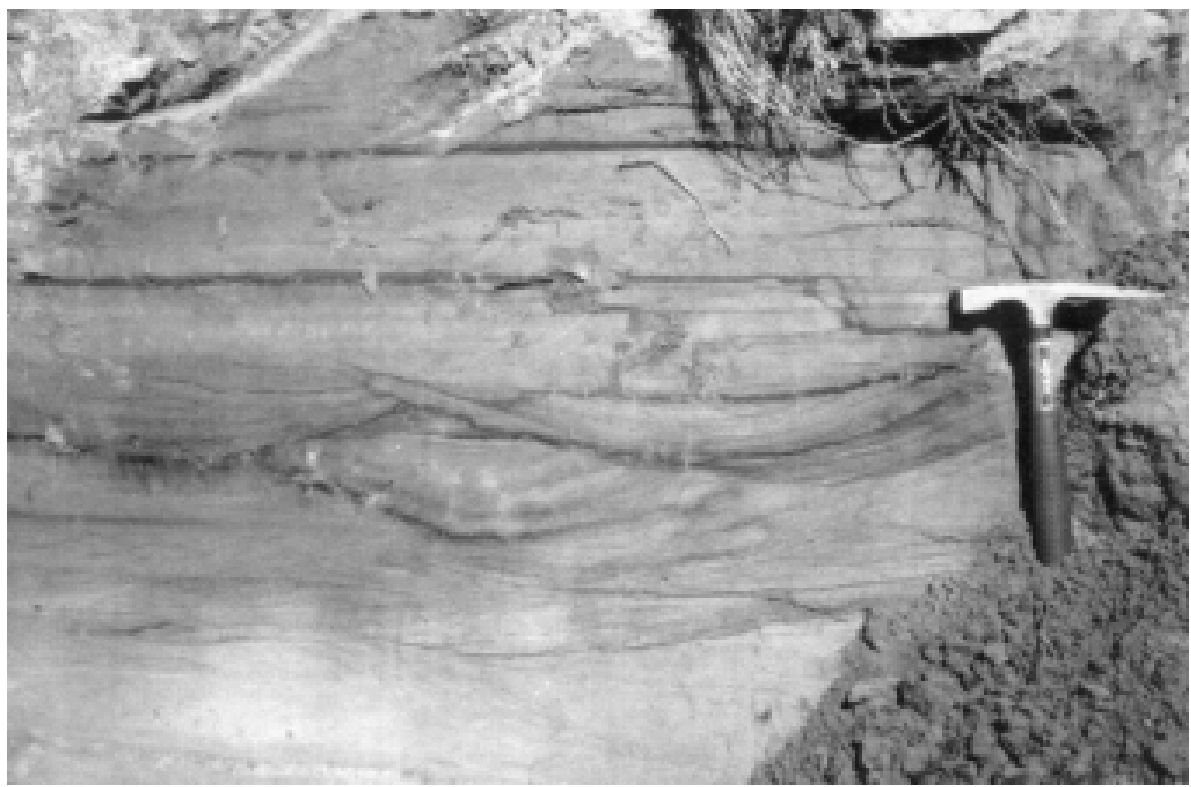

Fig. 3 - The primary hydrodynamic sedimentary structures, like parallel horizontal and through cross-beddings, observed in a shallow marine sand of Pleistocene age, near Paulo Lopes. 


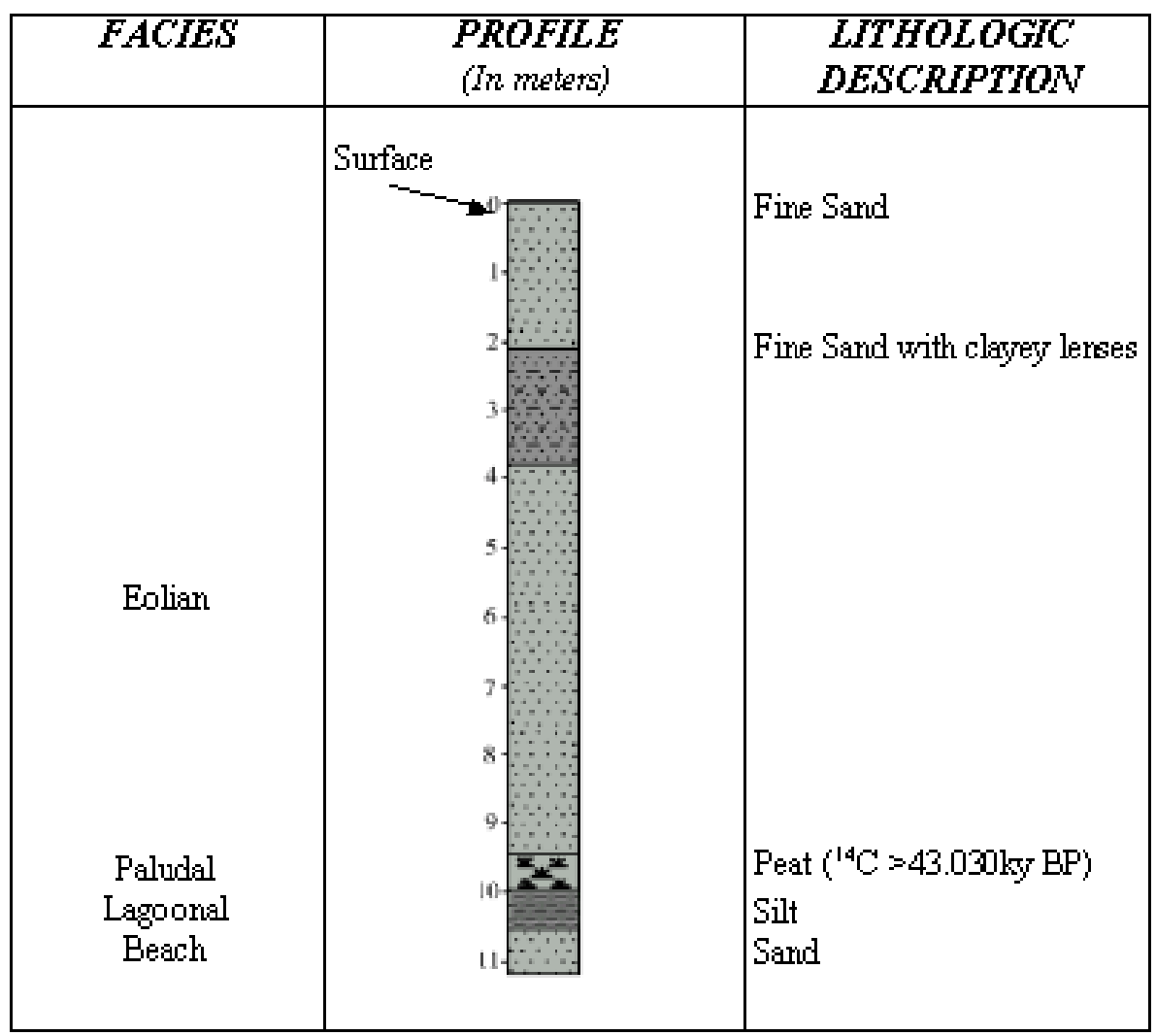

Fig. 4 - Drilling profile at north of Mirim Lagoon (28¹2’33”S/4043'05’'W), near Nova Brasília town (See geological map - Drilling A).

\section{THE HOLOCENE DEPOSITIONAL SYSTEM}

Partially abutted against the Pleistocene barrier island/lagoonal system III, there is the Holocene depositional system. This unit is attributable to the Santos Transgression of Suguio \& Martin (1978), along the State of São Paulo coastline, or to the Last Transgression of Bittencourt et al. (1979) along the State of Bahia coastline, being similar to the barrier island/lagoonal system IV of Villwock et al. (1986), along the State of Rio Grande do Sul coastline.

This system is related to the post-glacial transgressive episode whose culmination stage was attained about 5.1 ky BP, when a barrier island alignment was formed parallel to the shoreline, while drainage net was drowned. The subsequent regres- sive episode promoted the barrier island progradation following the lagoonal basin silting.

The paleoshorelines limited by ancient cliffs carved within Pleistocene terraces, presently representing the inner limit of the Holocene terrace, shows that this sea-level reached until about $4 \mathrm{~m}$ above the present one. Several terraces situated in different altitudes, and truncation of past morphological features nowadays observed on Holocene deposits, as well as along present lagoonal margins suggest that small scale sea-level oscillations occurred during the last $5 \mathrm{ky}$. They have been watched by the paleoindians who built the shell-middens widely distributed throughout this coastal plain.

The fluvial sediments supplied by the drainage net, added to sediments reworked by coastal dynamics, gave rise to intensive silting up and consequent 


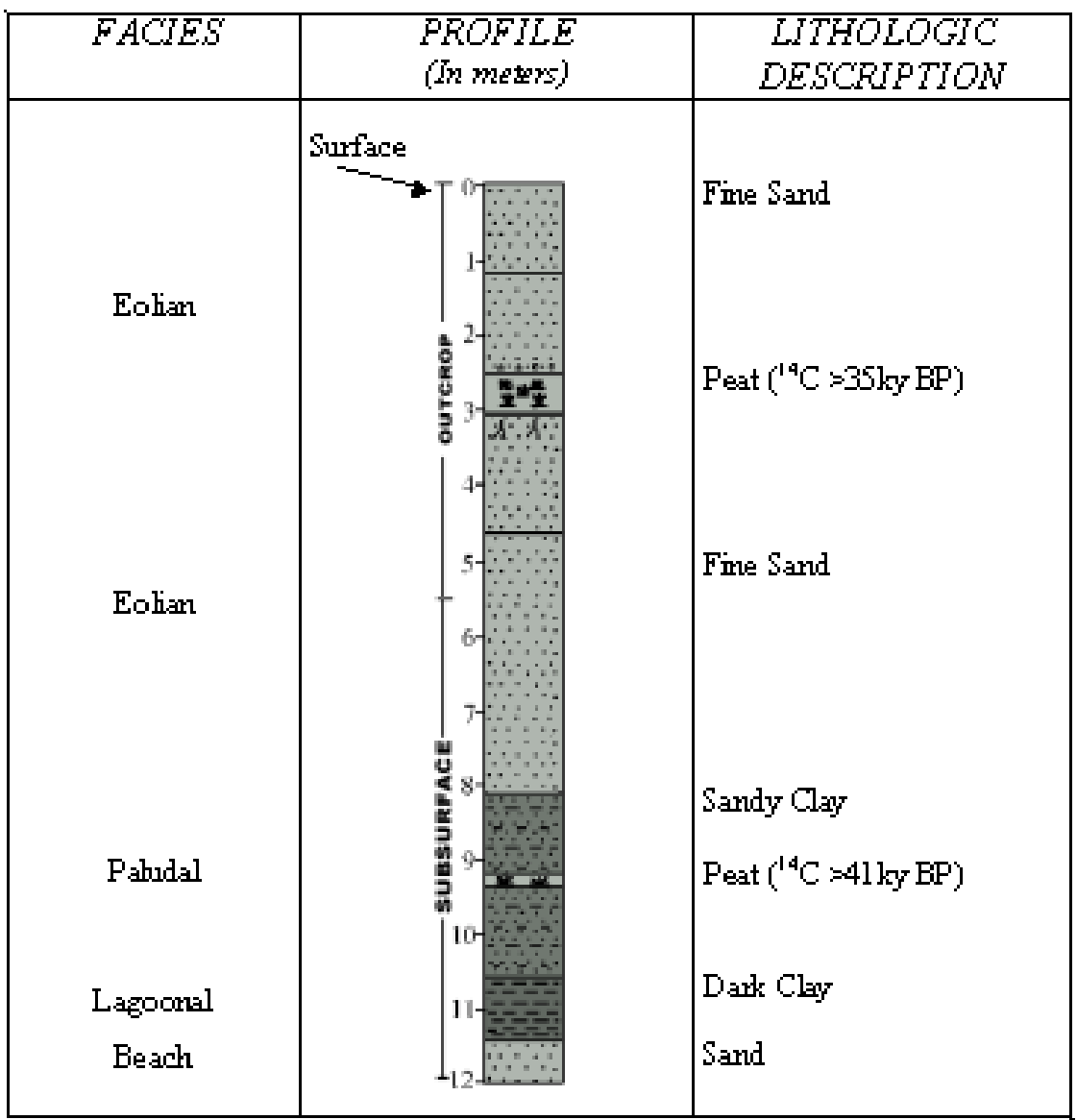

Fig. 5 - Drilling profile integrated with the outcrop data in Guaiúba Beach (28¹7’10’S/ $48^{\circ} 42^{\prime} 07^{\prime \prime} W$ ). (See geological map - Drilling B).

segmentation of the lagoonal bodies. The present shapes of these lagoons resulted from progradation of swampy margins, as well as growth of beaches and sand spits. In some places the total thicknesses of the lagoonal deposits, composed of sands, muds, biodetrital carbonates and peats, exceed $40 \mathrm{~m}$ and many of the depositional environments are still active.

The paludal facies of the Holocene lagoonal system is represented by organic matter rich muddy deposits, which corresponds to the terminal stage of the coastal lagoon siltation. A drilling within the paleolagoonal deposits at north of the Figueirinha lagoon $\left(28^{\circ} 39^{\prime} 01^{\prime \prime} \mathrm{S} / 48^{\circ} 58^{\prime} 43^{\prime \prime} \mathrm{W}\right)$ penetrated through peats, clays and shelly sands, from top to bottom (Fig. 6). A sample of peat from the top of the drilled section, dated in the previously mentioned laboratory, indicated an age of 1,380+70 yr. BP (NUTA-3310).

\section{PALEOGEOGRAPHIC EVOLUTION}

During the late Quaternary the southern Brazilian continental margin was submitted to many paleoenvironmental changes, as a consequence of some global phenomena. The most important of them is of climatic origin, being related to the northern hemisphere glacial and interglacial stades, which was represented along the Brazilian coastline through glacial eustatic sea-level changes.

The general scheme of the geological evolu- 


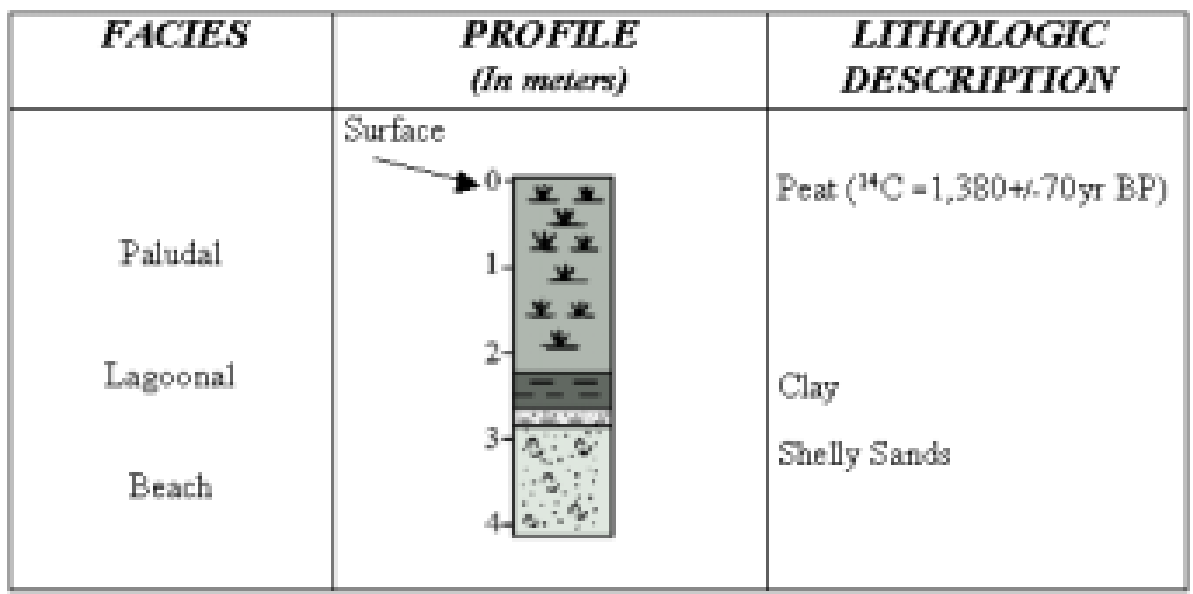

Fig. 6 - Drilling profile at north of Figueirinha Lagoon (28³9'01's/ $48^{\circ} 58^{\prime} 43$ ' W), near Jaguaruna town (See geological map - Drilling C).

tionary stages has been established by Suguio \& Martin(1987), with some modifications in ideas proposed by Martin et al. (1983), Suguio et al. (1985) and Villwock et al. (1986), which was adopted by Caruso Jr. (1995), and can be synthesized as follows.

\section{A) Stage I}

Maximum of the Pliocene regression - According to Maack (1949) the relative sea-level at that time could be at least $100 \mathrm{~m}$ below the present one, when most of the adjacent continental shelf has been covered by continental mass-movement deposits originated under semiarid paleoclimate (Bigarella \& Andrade, 1964).

\section{B) Stage II}

First Pleistocene transgressive/regressive episodeThe alluvial fans formed during the previous episode have been partially reworked, giving rise to barrier island/lagoonal system I. This event was not yet identified in the State of Santa Catarina southeastern coast.

\section{C) Stage III}

Second Pleistocene transgressive / regressive episode - Though discontinuously outcropping in the State of Rio Grande do Sul, represented by shallow marine and eolian deposits, apparently this episode was not so meaningfully recorded in this state.

\section{D) Stage IV}

Third Pleistocene transgressive/regressive episodeThis relative sea-level change episode was not very conspicuously preserved at this coast, where $8 \pm 2 \mathrm{~m}$ wave-built terraces are frequent. Peat samples from these deposits indicated their minimum age of about $40 \mathrm{ky}$, ratifying the previous idea that they are late Pleistocene in age, probably attributable to the Sangamon interglacial stage.

The following last glacial state of the northern hemisphere extended through the LGM (Last Glacial Maximum), so that about 18 ky BP the relative sea-level dropped to more than $100 \mathrm{~m}$ below the present one. Under these conditions the coastal plains, along the Brazilian coast attained the shelf break and fluvial valleys have been carved on the present continental shelf.

From $18 \mathrm{ky}$ BP the climate has ameliorated with consequent relative sea-level rise, which was not regular and continuous but interrupted by sev- 
eral stillstands, presently represented by more-orless preserved terraces. The consequent horizontal shoreline shift was initiated from $-130 \mathrm{~m}$ to the current sea-level, with four intermediary stillstands: the first one at $16 \mathrm{ky}$ BP between $-100 /-110 \mathrm{~m}$, the second one at $11 \mathrm{ky}$ between $-60 /-70 \mathrm{~m}$, the third one at $9 \mathrm{ky}$ BP between $-32 /-45 \mathrm{~m}$, and the last at 8 ky BP between -20/-25m (Corrêa \& Toldo Júnior, 1998).

\section{E) Stage V}

Maximum of the Holocene transgression - This episode was exhaustively studied along most of Brazilian coast (Suguio et al. 1985). The relative sea-level rise during this transgression drowned the downstream courses and lagoonal margins, eroding ancient marine terraces and giving rise to sand spits and barrier islands, which formed new lagoonal systems along the coast. Mollusk shells and wood fragments contained within lagoonal deposits indicated radiocarbon ages between 5 and 7 ky BP (Mendes 1993; Pitoni 1993), suggesting that the barrier islands installation occurred before the Holocene culmination stages (5.1 ky BP).

\section{F) Stage VI}

Construction of intralagoonal deltas - This phase corresponds to the intralagoonal or intra-estuarine deltas construction episode, within the lagoons formed during the previous transgression, with fluvial sediments, some of them still active like the Tubarão river intralagoonal delta.

\section{g) Stage VII}

Construction of Holocene wave-built terrace - The sea-level drop following the $5.1 \mathrm{ky}$ BP culmination stage originated the wave-built terrace abutted against the original barrier island, with the consequent shoreline progradation in general as regressive beach ridges. Several truncations of these beachridge systems, as well as many levels of marginal lagoonal terraces suggest that the dominantly regressive trend was momentarily interrupted by mi- nor transgressive episodes. The radiocarbon ages of the natural shell beds indicate that between 5 and 3 ky BP the relative sea-level was higher than today, with consequent expansion of the lagoonal areas frequently transformed into bays, and warmer paleotemperatures were favourable for great proliferation of mollusks in the area (Mendes 1993; Pitoni 1993).

Data obtained from the study of the Carniça (Hurt 1974), and Ponta das Almas (Piazza 1966; Hurt 1974) shell-middens, the second one situated in the Santa Catarina island, showed a sandy bed intercalation between shell beds of different ages. The lower bed presented a radiocarbon age of about $3 \mathrm{ky}$ and the upper of about $2.5 \mathrm{ky}$. These data suggest that a sea-level drop occurred between these times, when the shell-midden's site was probably abandoned. A radiocarbon age of peat samples from the Moçambique beach (Santa Catarina island) showed an age of 2,660 $\pm 170 \mathrm{yr}$. BP (Caruso, 1989), which seems to confirm this hypothesis of a gradual sealevel drop at that time.

The reoccupation of these archeological sites about $2.5 \mathrm{ky}$ BP would be possible due to a relative sea-level rise with consequent expansion of the lagoonal area, which remained at least until 1,380 \pm 70 yr. BP when the relative sea-level was about $2.0 \mathrm{~m}$ above the present one.

Based on the data obtained by Suguio et al. (1985), Martin et al. (1988) and Caruso (1989, 1995), a relative sea-level change curve for the last 7 ky in the area Florianópolis-Jaguaruna (Fig. 7) is outlined.

\section{THE CALCAREOUS SHELL BEDS AS THE MOST PROMISING MINERAL PROSPECT OF THE AREA}

The most important calcareous shell deposits in southern Brazil are associated to this portion of the State of Santa Catarina. The natural concentrations of shells are associated with lagoonal and estuarine muddy deposits and beach and shallow marine sands. They have been subjected to subsequent reworking due to the littoral hydrodynamics 


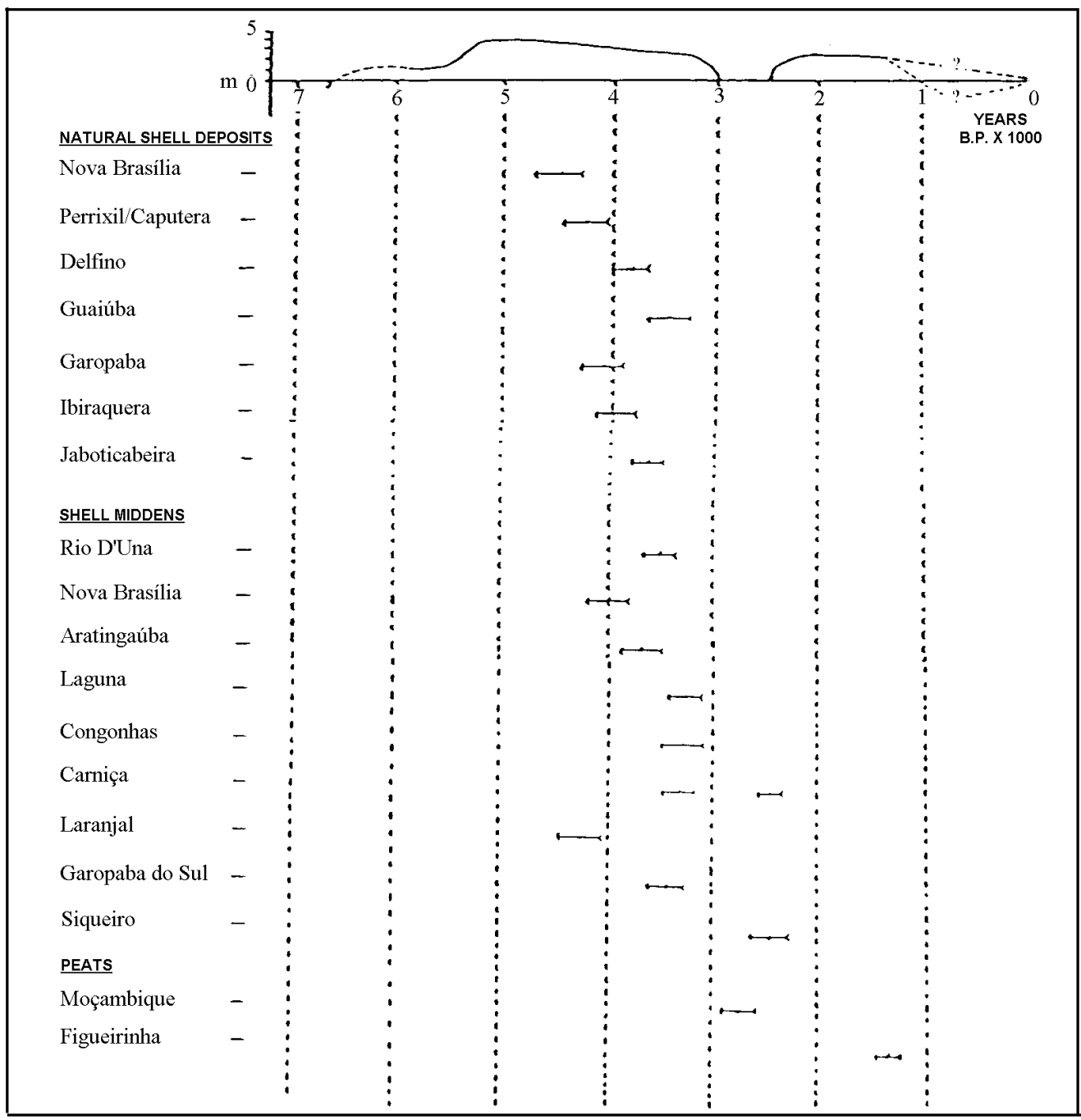

Fig. 7 - Relationship between radiocarbon ages of natural shell beds, shell-middens and peats with the sea-level curve outlined by Suguio et al. (1985), Martin et al. (1988) and Caruso Jr. (1989, 1995).

which originated lagoonal and marine beach facies, tidal channel facies, including flood tidal deltas, and transgressive residual shell facies (lag deposits).

All these shell deposits exploited until now are allochthonous in origin, and have been formed by concentration under high energy conditions. The high frequency of broken shells, the mixture of opensea, lagoonal and estuarine fauna, the presence of graded and cross-bedded structures are indicative of these processes.

In the Imbituba-Laguna region, at the eastern
Mirim-Imaruí-Santo Antonio lagoonal complex, there are some lagoonal spits which allowed economically exploitable concentration of shells, like in the Vila Nova, Guaiúba, Roça Grande, Ponta Rasa and Perrixil-Caputera deposits.

At northern extremity of this lagoonal complex, in the Nova Brasília region, there is a $4,000 \mathrm{~m}$ long, 420m wide deposit (Fig. 8), whose thicknesses change between 0.60 and $6 \mathrm{~m}$. According to Forti-Esteves (1986), Mendes (1993) and Pitoni (1993), the most abundant species of mollusks are: 
Heleobia australis (d'Orbigny, 1835), Cerithiopis greeni (Adams, 1839), Crepidula plana (Say, 1822), Nassarius viabex (Say, 1822), Tellina (Eurytellina) lineata (Turon, 1819) and Tagelus plebeius (Lightfoot, 1786). Among them, the first two species could be considered as estuarine, and the rest are littoral marine. Other species are represented by Neritina virginea (Linnaeus, 1758), Cerithium stratum (Born, 1778), Bulla striata (Bruguière, 1792), Ostrea equestris (Say, 1834), Codakia costata (d'Orbigny, 1842), and Anomalocardia brasiliana (Gmelin, 1791).

According to Martin \& Suguio (1986) the radiocarbon ages of shells from this area indicated $4,490 \pm 200$ yr. BP, but as they are allochthonous this age could be suspicious as depositional age.

Observations in mining fronts of Nova Brasília deposits allowed to distinguish tabular great scale cross-bedded units composed alternately by more sandy and more shelly beds. In detail these beds exhibit reverse grading due to grain and shell flows and sorting processes involved in the migration of the bedforms. These features suggest that the transport of these materials occurred as tractional current bars.

A representative profile of this deposit provided the data for reconstruction of the process involved in its deposition. Other mining fronts in the same deposit show many similarities, being different in the size of the outcropping area and inclinations of the cross-bedded units. A cross-cut parallel to the paleocurrent direction shows a serie of cross-bedded units preferably originated by avalanching through the frontal surface of the deposit (Fig. 9).

This avalanching is attributable to the unstable situation originated by the intense deposition of sandy-shelly material near the ridge of the frontal surface. The distinct sorting along the beds suggests that these avalanching processes have been intermittent.

A possible interpretation for the origin of this deposit is that the Pleistocene terrace at northern part of the lagoon had functioned as a blockage for the subaqueous sediment transport from south to north. The currents responsible for the reworking of the pre-existing shell beds of the lagoonal bottom were probably canalized toward the NW as a function of this obstacle, so that a considerable current velocity decreasin occurred, also as a function of proximity to the rocky hills at the $\mathrm{W}$, propitiating the deposition (Fig. 10).

This hypothesis points out that the essential factors for biodetrital concentration are as follows: great availability of shells in the lagoonal bottom and existence of sufficiently vigorous currents to transport so voluminous shell debris.

Southward from the Jaguaruna town there are the Jaboticabeira and Camacho, as two potentially important calcareous shell bed deposits. The Jaboticabeira deposit is represented by several occurrences, probably forming part of a partially eroded shell deposit (Fig. 11).

Within the investigated area this shell deposit is $1,300 \mathrm{~m}$ long in the NW-SE direction and its width varies from 150 to $1,000 \mathrm{~m}$. At one of the described mining fronts representing an approximately transversal section there are cross-beddings dipping toward opposite sides from the middle portion, which is characterized by horizontal and parallel layers exhibiting graded beddings. At the base, there are unbroken shells but toward the top the shell fragments become gradually finer and mixed with the quartzose sand. The thicknesses of the shell bed are variable between 0.5 and $4.5 \mathrm{~m}$ with different grades of purity.

The calcareous shell beds are overlain by a thick mud layer which is in turn covered by peats and organic matter rich muddy layer. The mollusk fauna is apparently similar to that found in Nova Brasília deposit. Shell sample collected from the top of a bed was dated at 3,720 $\pm 60 \mathrm{yr}$. BP (NUTA-3315). The primary sedimentary structures, as mentioned above, suggest that this shell bed was probably deposited as bayhead foreshore bar migrating due to waves and currents, when the relative sea-level was higher than today. 


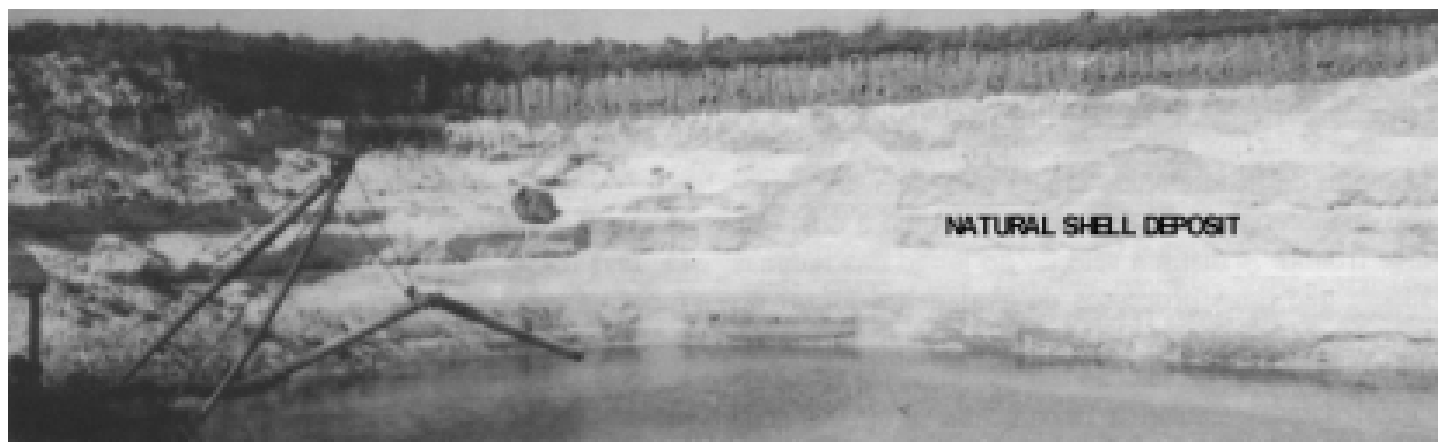

Fig. 8 - Calcareous shell deposit in Nova Brasília at north of the Mirim-Imaruí-Santo Antonio lagoonal complex.

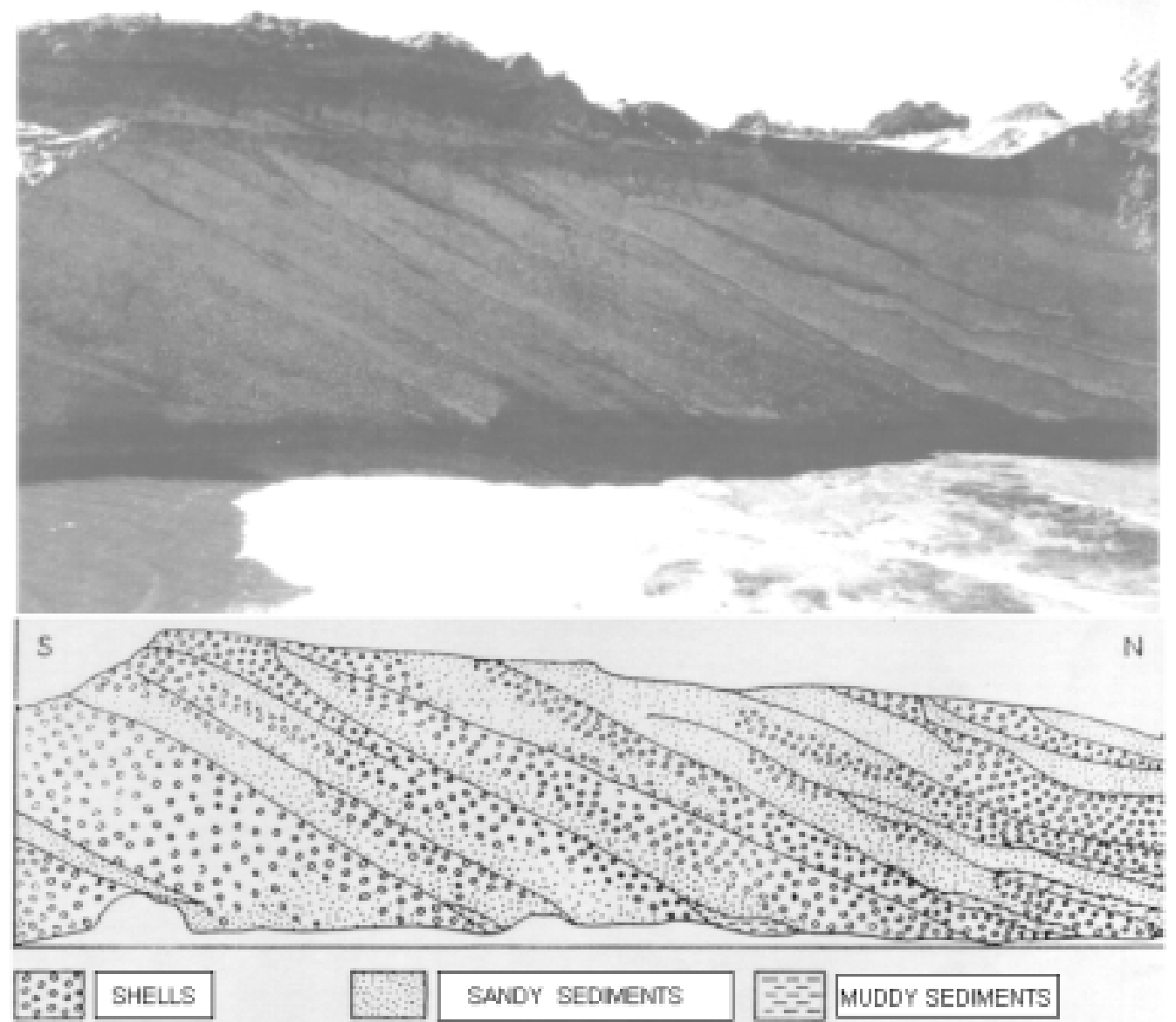

Fig. 9 - Geologic profile of Nova Brasília calcareous shell deposit along the paleocurrent direction, with a sequence of beds showing avalanching processes on the frontal surface. 


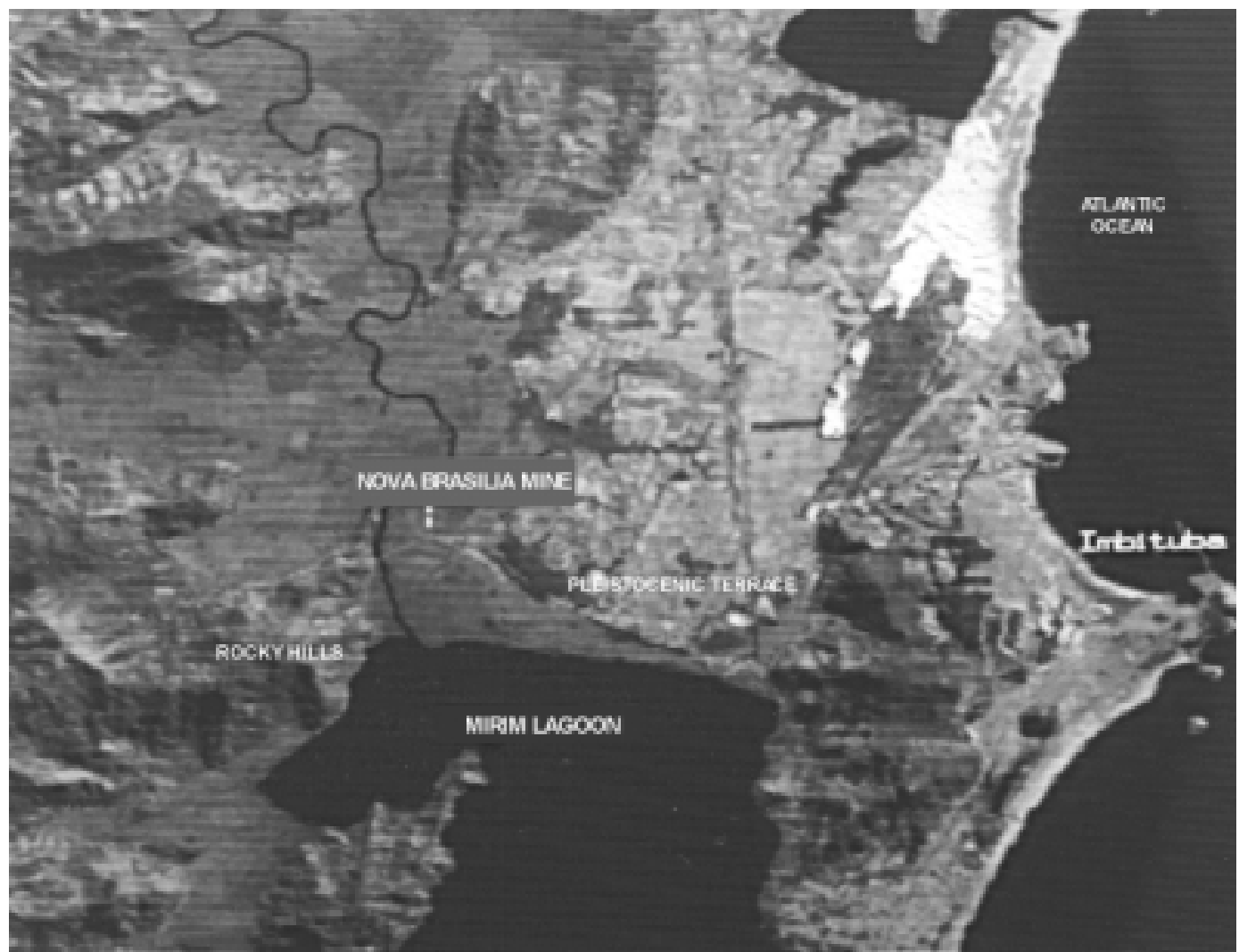

Fig. 10 - Geographic situation of the Nova Brasília calcareous shell deposit.

Another voluminous calcareous shell bed is found in Camacho, near Garopaba do Sul lagoon, embracing not only the eastern margin of the homonymous lagoon, where was partially exploited, but extends below the beach-ridge closing this lagoon. The deposit is about $3,000 \mathrm{~m}$ long in NE-SW direction and 950 to $1,650 \mathrm{~m}$ wide, with the shell bed thickness of 0.20 to $2.00 \mathrm{~m}$. Its purity increases toward the surface, being less pure at depth. These characteristics suggests that this deposit was probably originated as flood-tidal paleodelta.

\section{CONCLUSIONS}

The geological evolution of this sector of the State of Santa Catarina was reconstructed thanks to a series of data obtained from Cenozoic deposits occurred in Imbituba and Laguna regions. The mini- mum ages of the Pleistocene sediments, whose ages were only inferred until now, were confirmed by ${ }^{14} \mathrm{C}$ method in peat samples from underlying deposits. The Holocene sediments, related to the last postglacial transgressive episode, showed their distribution through complex depositional environments, whose paleogeographic reconstructions became possible thanks to a series of ${ }^{14} \mathrm{C}$ dates from peat and shell samples collected in the deposits.

Concerning to the geological evolution of the coastal plain, in the area, seven evolutionary stages have been inferred. The relative sea-level change curve for this region, during the last 7,000 years, was based on Martin et al. (1988), partially modified by informations obtained during this work.

The main mineral resource of this coastal plain are the calcareous shell deposits, followed by peats, heavy minerals, diatom oozes, sands, gravels and 


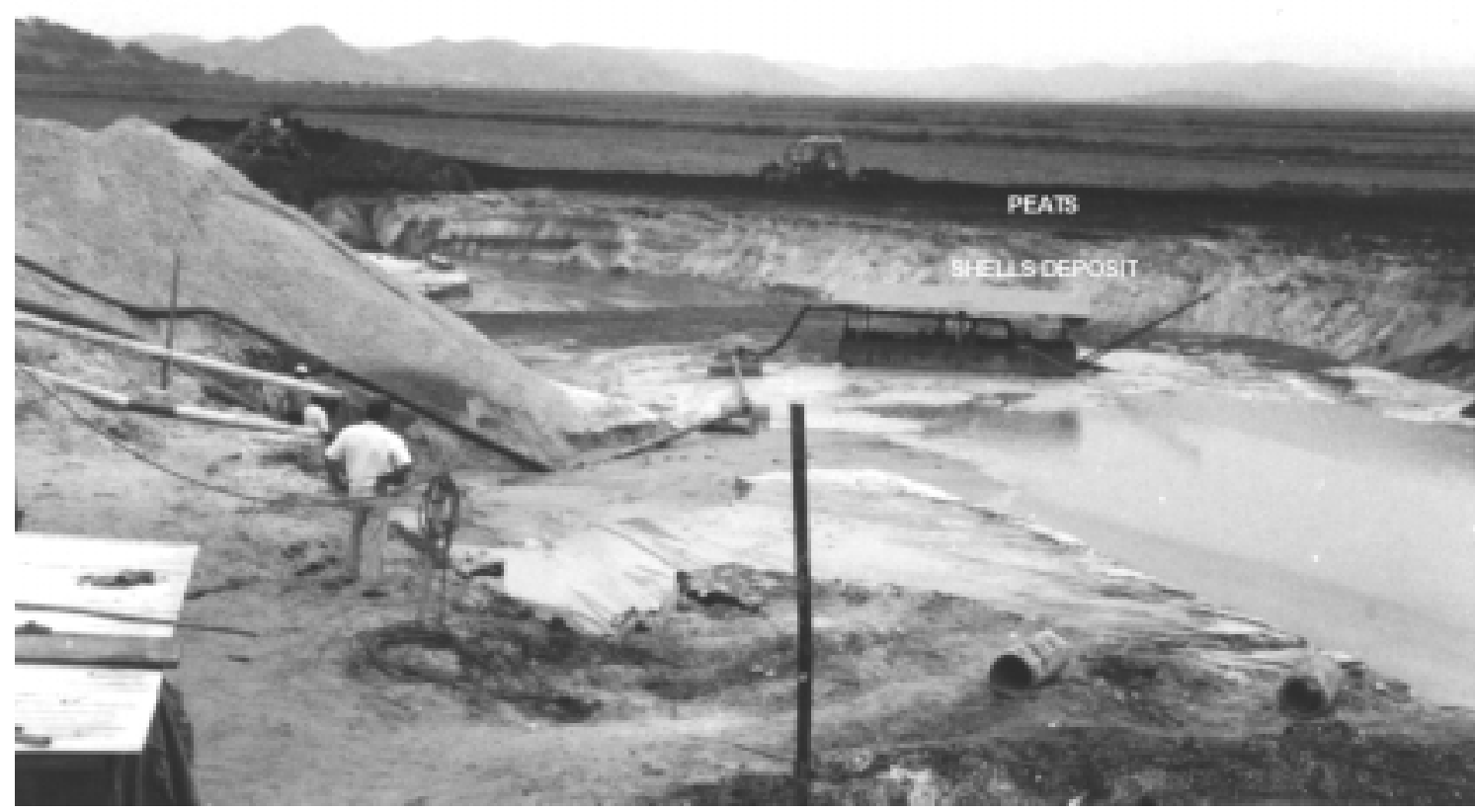

Fig. 11 - Exploitation of the calcareous shell bed of Jaboticabeira, near Jaguaruna town.

clays.

The most important calcareous shell deposits in the southern Brazil are situated in this sector of the Santa Catarina State coast, and due to their relevance for the regional economy, the main geological characteristics of these deposits have been here studied.

The concentration of shells are related to muddy facies accumulated within lagoonal and estuarine environments, and to sandy beach and shallow marine facies. Probably, they are the most important source for the bioclastics, that was laterly submitted to littoral dynamics reworking, and redeposited as lagoonal and marine beach facies, tidal channel facies, sand bar washover fan facies, flood tidal deltas and transgressive shelly lag deposits. All these deposits have been economically exploited, and they look to be composed almost entirely of allochthonous shells, concentrated and accumulated by high environmental energy processes.

\section{REFERENCES}

Bigarella JJ \& Andrade GO. 1964. Considerações sobre a estratigrafia dos sedimentos cenozóicos de Pernambuco (Grupo Barreiras). Arq Inst Cien Terra 2: $2-14$.

Bigarella JJ \& Becker RD. 1975. Sea level changes. In: International Symposium on the Quaternary. $\mathrm{Cu}$ ritiba. Topics for discussion. Bol Paran Geocien 33: 245-251.

Bittencourt ACSP, Martin L, Vilas Boas GS \& FLEXOR JM. 1979. The marine formations of the coast of the State of Bahia. In: International Symposium on Coastal Evolution in the Quaternary. São Paulo, 1978. Proceedings, São Paulo, IGCP Project 61: 232-253.

CARUSO JRF. 1989. Geologia e características ambientais da Lagoa da Conceição, Ilha de Santa Catarina. Dissertação de Mestrado, Inst. de Geociências, UFRJ, 120 p. 
CARUSO JRF. 1995. Mapa geológico e recursos minerais do sudeste de Santa Catarina (Escala $=1: 100.000)$. Texto explicativo e mapa. DNPM, Brasília, 52p.

CORRÊA ICS \& Toldo JúnIOR EE. 1998. The sea-level stabilization in the Rio Grande do Sul continental shelf, Brazil. An Acad Bras Ci 70: (no prelo).

Forti-Esteves IR. 1986. Análise faunística do concheiro natural de Nova Brasília, Santa Catarina. Rel Fin Pesq Florianópolis, DNPM. (Inédito)

Gonçalves A, Oliveira MAM \& Motta SO. 1979. Geologia da Bacia de Pelotas e da Plataforma de Florianópolis. Bol Tec Petrobrás 22: 156-174.

HURT WR. 1974. The interrelationships between the natural environment and four sambaquis, coast of Santa Catarina, Brazil. Indiana University Museum. Occasional Papers and Monographs, 1: 23p.

MAack R. 1949. Espessura e seqüência de sedimentos quaternários no litoral do Estado do Paraná. Arq Biol Tec 4: 271-286.

Martin L \& Suguio K. 1986. Coastal quaternary deposits of the states of Paraná and Santa Catarina. In: International Symposium on Sea Level Changes and Quaternary Shorelines. São Paulo, 1986. Special Publication. 1: 124p.

Martin L, Domingues JML, Suguio K, BittenCOURT ACSP \& Flexor JM. 1983. Schéma de la sédimentation quaternaire sur la partie centrale du littoral brésilien. Cahier ORSTOM, Sér. Géol. 13: 59-81.

Martin L, Suguio K, Flexor JM \& Azevedo AEG. 1988. Mapa geológico do quaternário costeiro dos estados do Paraná e Santa Catarina. DNPM (Serie Geologia 28, Seção Geologia Básica 18), 40p.

Mendes ILV. 1993. Malacofauna, paleoecologia e bioestratigrafia de sedimentos holocênicos da planície costeira de Imbituba e Imaruí, Santa Catarina, Brasil. Tese de Doutorado, Inst. de Geociências, UFRGS, 309p. (2 volumes).
Piazza WF. 1966. O sambaqui da Ponta das Almas. In: Estudos de Sambaquis, UFSC, Série Arqueologia, 2: 6-22.

Pitoni VLL. 1993. Moluscos cenozóicos da subsuperfície em Imaruí, Santa Catarina, Brasil: paleoecologia, transgressões e regressões. Tese de Doutorado, Inst. de Geociências, UFRGS, 269p. (2 volumes).

Suguio K \& Martin L. 1978. Quaternary marine formations of the states of São Paulo and southern Rio de Janeiro. In: International Symposium on Coastal Evolution in the Quaternary, São Paulo, 1978, Special Publication, 1, São Pau7lo, IGCP Project 61, 55p.

Suguio K \& Martin L. 1987. Classificação de costas e evolução geológica das planícies litorâneas quaternárias do sudeste e sul do Brasil. In: Simpósio sobre Ecossistemas da Costa Sul e Sudeste Brasileira. 1987, Anais, Cananéia. Acad Ci Est São Paulo 2: $1-28$.

Suguio K \& Petri S. 1973. Stratigraphy of the IguapeCananéia lagoonal region sedimentary deposits, São Paulo State, Brazil. Part I: Field observations and grain size analysis. Bol IG, Inst de Geociências, USP, 4: $1-20$.

Suguio K, Martin L, Bittencourt ACSP, Dominguez JML, Flexor JM \& Azevedo AEG. 1985. Flutuações do nível relativo do mar durante o Quaternário superior ao longo do litoral brasileiro e suas implicações na sedimentação costeira. Rev Brasil Geoc 15: 273-286.

Villwock JA, Tomazelli LJ, Loss El, Denhardt EA, Horn Filho NO, Bachi FA \& Denhardt BA. 1986. Geology of the Rio Grande do Sul coastal province. Quaternary of South America and Antarctica Peninsula, 4: 79-97. 